\title{
The Application of Double Qualified Teachers in the Teaching of Ideological and Political Course for the Transformation and Development Model Universities
}

\author{
Hongwei Ma
}

Xuchang University, Xuchang 461000, Henan, China.

Project: Xuchang college level education and teaching reform project: Research on the role of double qualified teachers of Transformation and development model Universities in the teaching of Ideological and political theory course. (No.: xcu2018-zz-016)

Abstract: The ideological and political teachers are in a weak link in the construction of the double qualified teachers in the transformation and development model universities. We must give full play to the unique role of the double qualified teachers in the ideological and political course teaching, in order to strive to improve the teaching quality and enhance the effectiveness. On the basis of preliminary practice and exploration, we should take the road of optimizing incentive with restraint mechanism and practical training.

Keywords: Double Qualification; Universities in Transition; Ideological and Political Course

With innovation and entrepreneurship becoming the theme movement of the times, the development of higher education also ushered in a new opportunity. According to the medium and long-term plan of the national college entrance examination education development, colleges and universities began to implement classified development and differentiated positioning. Based on the actual needs of the development of higher education in the new era, most local undergraduate colleges and universities carried out transformation and development, and changed to local and application-oriented direction. Some of the transformation of colleges and universities have been in the forefront of the times, and have achieved great success, becoming the transformation development model university. Double qualified teachers are the specific embodiment and internal requirements of the transformation and development of undergraduate colleges and universities in terms of teaching staff. A team of double qualified teachers with noble morality, profound knowledge and exquisite technology is an important symbol to measure the success of the transformation of colleges and universities. Teachers of ideological and political theory course are often in a weak link in the construction of double qualified teachers for the transformation and development model universities. We should give full play to the unique role of double qualified teachers in the teaching of ideological and political theory courses, and strive to improve the teaching quality of ideological and political theory courses in colleges and universities, changing "low value class" into "golden class", so that the teachers of ideological and political course in transformation and development model universities can really implement solicitous advice: "Political teachers should plant the seeds of truth, goodness and beauty in students' hearts and guide them to buckle the first button of life" ${ }^{\text {"[ }]}$ by improving the teaching effectiveness and pertinence of ideological and political theory course.

\section{Preliminary exploration on the construction of double qualified teachers in ideological and political theory course}

With the decision-making and positioning of the national education authorities on the classified and differentiated development of colleges and universities, the double qualified teachers gradually pay more attention to practical teaching and are applied in various fields in higher education. This positioning is reflected in the teaching of ideological and political theory in colleges and universities, and some them have carried out beneficial practical exploration. The application of double qualified teachers in the teaching of ideological and political course in colleges and universities is mainly reflected in the following aspects:

Copyright $\odot 2020$ Hongwei Ma

doi: 10.18686/ahe.v4i10.2903

This is an open-access article distributed under the terms of the Creative Commons Attribution Non-Commercial License (http://creativecommons. org/licenses/by-nc/4.0/), which permits unrestricted non-commercial use, distribution, and reproduction in any medium, provided the original work is properly cited. 


\subsection{Fully embody the specific requirements of double qualified teachers in ideological and political theory teaching}

From the source, the application-oriented training mode of school and enterprise cooperation in modern higher vocational education has given birth to the popularization and application of "double qualification" in the teaching of ideological and political theory in colleges and universities. In addition to the general subject requirements and knowledge background of ideological and political theory courses, teachers of ideological and political theory courses should also strive to cultivate themselves into not only competent for the teaching of ideological and political theory courses in model universities, but also good at using new media technology and information technology for transformation classroom teaching, combining online with offline teaching, in order to cultivate college students to be applied talents for the enterprise in propaganda and work of ideological and political theory. It is also necessary to cultivate college students to establish and carry forward advanced enterprise culture, and explore successful cases of enterprise, so as to explore the path and take the lead in promoting the transformation and development of the ideological and political theory course teaching reform in model colleges and universities. Therefore, we should deeply understand the important value of the construction of double qualified teachers of Ideological and political course in the transformation and development of colleges and universities.

Colleges and universities have become the forefront and highland of ideological work in the whole social structure. In the process of transformation and development of colleges and universities, the knowledge and theoretical literacy of ideological and political course teacher team, the basic cultivation of subject and the teaching methods of practical and innovative education have become the key factors that directly affect college students in the aspects of scientific theory armed, the promotion of socialist core values and the improvement of ideological awareness, and it directly related to whether college students can enhance the "Four Self-confidence". We should learn advanced socialist culture and grasp the situation and policy hot spots, as well as study and implement the party's line, principles and policies, so as to truly achieve the unity of knowledge and practice, and closely combine scientific ideological theory with the great practice of building socialism with Chinese characteristics.

\subsection{Strive to improve the effectiveness of double qualified teachers for the ideological and political course teaching in colleges and universities}

After entering the new era, China's higher education has not only entered the stage of "popularization", but also entered the transformation era of local colleges and universities with classified development. It has become the main theme of the times to focus on the connotative development and start the high-quality development of higher education. Improving the quality of education and teaching has become the top priority of the development of higher education, and is also a hot issue of concern to the whole society. Through strengthening the teaching concept of taking students as the main body, doubt qualified teachers of ideological and political course pay more attention to the reasonable organization of teaching combined with practice, and innovate classroom teaching methods based on the vivid social practice experience of double qualified teachers with doubt capacities, in order to lead students to expand teaching activities to carry out rich practical exploration and theoretical research, with the purpose of which is to enhance the achievement degree of effectiveness for the ideological and political education in colleges and universities, and focus on solving the marginalization of ideological and political teachers in the construction of double qualified teaching staff.

There is no doubt that the rapid development of higher education objectively results in the transformation and development of local colleges and universities in the ideological and political course teacher team construction. However the need of constantly introducing young teachers forms the imbalance level of knowledge, professional ability and education and teaching of Ideological and political course teachers. In the process of transformation and development, professional teachers have natural advantages in transformation ability, knowledge structure and school support conditions. With more difficult transformation and process, the ideological and political teachers are easy to be marginalized by the process of transformation and development. At the same time, senior ideological and political teachers have more teaching experience than young teachers, and have more advantages in theoretical knowledge accumulation and classroom teaching experience. However, in the innovation of teaching ways and methods, it is easy to get out of touch with the times, and the time, energy, mental strength as well as endogenous motivation for teaching transformation are relatively insufficient.

\section{Path optimization of the construction of double qualified teacher team in ideological and political theory course}

\subsection{Strengthen system of performance and establish scientific and reasonable incentive and restraint mechanism}

The depth and difficulty in transformation and development of colleges and universities are teachers, and scientific and 
perfect system guidance is the magic weapon to overcome difficulties. The transformation of colleges and universities should reform the existing system and mechanism, through the establishment and improvement of the incentive mechanism, training mechanism, development mechanism for ideological and political course teachers, in order to guide and encourage ideological and political teachers to develop in the direction of double qualified teachers. These positive incentive mechanisms can not only enhance the sense of professional honor, realistic satisfaction and welfare fairness of ideological and political teachers, but also condense the centripetal force of Ideological and political teachers with attraction enhancement. Another driving force of the transformation of dual qualification is from the constraint evaluation mechanism. Moderate transformation pressure helps to clarify the direction of teacher development and improve the comprehensive quality and professional skills of teachers. It can urge the ideological and political teachers to keep pace with the times and strengthen the theoretical study and practical application. The pressure of the evaluation mechanism can promote the ideological and political teachers to actively transform into doubt qualification.

\subsection{Strengthen the practical training of ideological and political course teachers in the transformation and development model universities}

Both the world and China are facing "great changes not seen in a century"[2]. For higher education, the transformation and development of local undergraduate universities is a "great change". The strategic measure to deal with this situation is to remodel the teaching staff in all aspects, at different levels. In this arduous historical task, the quality improvement of Ideological and political theory teachers depends on comprehensive, systematic and professional transformation training and cultivation. The specific implementation paths are as follow: Firstly, the transformation and development of model colleges and universities should strengthen the top-level design, doing a good job in teacher training and external introduction planning, and start with the upgrade of academic qualifications of ideological and political theory courses teachers. It is also necessary to formulate preferential policies for financial support, and strengthen the system construction for system guidance, as well as promote the transformation of double qualification through the improvement of academic qualifications of teaching staff. Second, according to the subject background, knowledge level and development direction of the existing ideological and political theory teaching staff, give full play to the teacher development center to organize targeted, hierarchical and professional systematic training, and expand to legal practice, psychological consultation, theoretical propaganda, information technology application, etc. For the new young teachers, we can invite excellent double qualified teachers in and out of the school to teach the professional theory, practical professional skills, basic teaching skills for double qualification and classroom teaching organization strategies. Combined with the examination of university teachers' qualification certificate, through the training of teachers' ethics, education laws and regulations, and teaching skills training, the professional ethics level and professional quality of teachers of Ideological and political theory course can be improved, as, well as the practice and expansion training can be carried out continuously. Third, the double qualification focuses on practice. We should constantly strengthen the practical teaching of ideological and political theory course, and expand various forms of practical teaching types, walking classroom, on-site teaching, situational teaching, flipped teaching and other new teaching methods combining theory and practice, so as to constantly expand the practical teaching channels of ideological and political theory course. We should give full play to the rich red cultural resources, and establish the red education base as well as carry out the red practice education. By using the vivid practice of socialism with Chinese characteristics, teachers can lead guide the students to perceive the construction achievements, and feel the great changes of the times, in order to devote themselves to the great rejuvenation of the Chinese nation. Through rich and vivid training forms and practice forms, the overall quality of the ideological and political theory course teachers in the transformation and development model colleges and universities and the level of double qualified teaching staff with double qualifications can be further improved ${ }^{[3]}$ 。

\section{References}

1. Xi J. Held a forum on teachers of ideological and political theory courses, emphasizing the spirit of China's socialist ideology in the new era, cultivating people through the spirit, implementing the party's educational policy and implementing the basic task of the moral education. People's Daily 19 Mar 2019.

2. Wu Z. An interpretation of the "unprecedented great change in the world in a century". Beijing Daily 6 Jan 2019.

3. Wang Y. Strengthen the construction of teachers' team of ideological and political course, and do a good job in improving the quality and level of ideological and political course. University Teaching in China 2019; (4). 